\title{
Determinant Factor of Transformational Leadership in the Age of Globalization
}

\author{
Rajamemang $^{1}$, Tahir Kasnawi ${ }^{2}$, Anshari ${ }^{3}$, Fakhri Kahar ${ }^{4}$, Rusdi Maidin ${ }^{5}$ \\ ${ }^{1,5}$ Universitas Bosowa \\ ${ }^{2}$ Universitas Hasanuddin \\ 3,4 Universitas Negeri Makassar \\ E-mail: rajamemang@gmail.com
}

(Received: March-2019; revised: May -2019; published: June -2019)

\begin{abstract}
This study aims to determine the supporting and inhibiting factors of Transformational Leadership in the Age of Globalization. The research location was conducted at Bosowa University. The technique of collecting data uses observation, interviews, FGD. Data analysis techniques use the theories of Miles, Huberman and Saldana (2014). The results of the study show that the determinant factors in this study can be seen from two factors: university supporting factors and inhibiting factors. Supporting factors: it has been illustrated that the Chancellor as a leader has a network that has been developed both at the local, regional, national and international levels. Furthermore, it is supported by adequate learning process facilities. So as to be able to compete with other universities in Indonesia. The inhibiting factors are the availability of limited teaching staff.
\end{abstract}

Keywords: Determinant Factor; Globalization; Development.

\section{INTRODUCTION}

The success of an organization in the era of globalization in achieving goals is determined by various factors, such as human resources, facilities and infrastructure as well as the system that regulates it. (M. S. Saggaf, Akib, Salam, Baharuddin, \& Kasmita, 2018; M. S. Saggaf \& Salam, 2017; S. Saggaf, Salam, Kahar, \& Akib, 2014; Salam, 2015; Salam \& Rosdiana, 2016). The figure of a leader is the thing that most supports the success of an organization (Adams, 2011; Kragt \& Guenter, 2018; Mascia, Dal Pubel, \& Sartori, 2013; Nasila \& Akib, 2014; "Organizational Effectiveness," 2013). Therefore, a leader, of course, must have special expertise so that he is able to oversee every vision and mission that is the goal of the organization. This is because there are many challenges that must be faced in facing a change. The changes that often occur are: environmental changes and cultural shifts have influenced the dynamics of leadership. Therefore leadership that plays an important role in every college or in every organization faces the era of globalization in all fields.

One of the leadership that must be possessed today in welcoming the era of globalization is transformational leadership (Falk, 2013; Mac Ruairc, 2013; Maheshwari \& Yadav, 2019; Taylor, Pearse, \& Louw, 2013). The leadership in its development has an emotional bond with subordinates and is able to realize the organization's vision and mission (Anderson \& Sun, 2015; Antonakis \& House, 2014; Cetin \& Kinik, 2015; Hetland, Hetland, Bakker, \& Demerouti, 2018;

Copyright (C) 2018 Universitas Negeri Makassar. This is an open access article under the CC BY license (http://creativecommons.org/licenses/by/4.0/) 


\section{4 | Jurnal Administrare: Jurnal Pemikiran Ilmiah dan Pendidikan Administrasi Perkantoran Volume 6 No. 1 January-June 2019. Pages 73-78}

Li, Arvey, Zhang, \& Song, 2012; Phaneuf, Boudrias, Rousseau, \& Brunelle, 2016; van Dierendonck, Stam, Boersma, de Windt, \& Alkema, 2014). In addition, there are other factors that support the realization of the organization's vision and mission are good good governance. When these factors, support it will facilitate the achievement of the organization's vision and mission.

Bosowa University, South Sulawesi Province is a university which is one of the private universities that organizes education, research and community-based information technology (IT), and develops science, technology and art (IPTEKS) that are useful for humanity, implementing collaboration with agencies government and business world both domestically and abroad to develop quality human resources that are intelligent, religious, entrepreneurial. Various improvements have been made in a short period of time, in 2015 bringing the University of Bosowa to win the Best Leading University of the Year awarded by the Indonesia Achievement Center.

The leaders at the Bosowa University in Makassar should continue to exist in the fight for the quality of their leadership and still maintain the views of the community, as well as still exist in academic achievement, exist in carrying out activities; training, education, seminars, courses, workshops, basic leadership training (LDK), as well as lecturers are required to attend higher education.

\section{METHOD}

This study uses a qualitative approach. Efforts to find out the reality of the services provided by Bosowa University. So as to be able to present the real reality. The research location was conducted at Bosowa University. This is because Bosowa University is one of the private universities that has high achievements as a private university in eastern Indonesia. Data collection techniques were carried out by field observations, interviews, Focus Group Discussion (FGD). The data analysis technique used is interactive model analysis (Miles, Huberman, \& Saldana, 2014).

\section{RESULT AND DISCUSSION}

Efforts to develop a university, the Chancellor of the university certainly needs a strategy in realizing the vision and mission that will be carried out. In order to look at the vision of the mission of Bosowa University, there are two factors that support such as: Supporting factors and Inhibiting Factors.

\section{Supporting factors}

This factor is certainly very instrumental in realizing the ideals of the university. One of the supporting factors of the Bosowa University Chancellor is to have a network with other agencies to support alumni to be employed. Alumni are graduates of a college or university. According to the Indonesian language dictionary alumni are people who have attended or graduated from a college. The existence of alumni is very influential in improving the quality of 
an agency. When alumni work in a company, alumni will bring the good name of the alumni university from.

In addition, alumni can also help their alma mater by providing useful input or by providing job information. But currently there are still many students who do not know alumni who come from their universities so that the role of alumni does not run optimally, including Bosowa University. Many benefits can be obtained if the alumni bond is well established. Among them, such as strengthening relations between alumni, making it easier to find job information, such as project offers from alumni for their juniors.

In addition to the relationship between alumni with junior relations between fellow alumni is also very important, because it can share experiences about the fields underway and share knowledge with others. Alumni as graduates from an institution are also expected to be able to build a good network and image outside. With good network and image built by alumni, later it will make it easier for juniors to find work. The lack of access to information about alumni at the University is one of the factors that makes the role of alumni not run well.

The network is another institution that supports Unibos alumni to be employed. in several Bosowa companies. In line with that, based on the results of the author's observation, from the interviews that at the Bososwa University the chancellor's program was for cooperation programs, all private agencies. The goal is for alumni to be accommodated in the agency, and based on agreement and cooperation with the agency. including how many Bosowa companies. In addition to the time for new student meetings, the children are informed about the jobs that will come after the alumni. So the alumni are employed by Bosowa companies, totaling 55 business and social units that have alumni certificates, the University being the main consideration for absorbing workers. by forming an institution formed by Tracer by alumni.

Another supporting factor that is able to realize these ideals is the availability of adequate facilities. As well, adequate classroom facilities make the classroom learning process conducive. In connection with that based on the observations of the author from the results of interviews that the author can be interpreted that the factors that support the development of Unibos, in terms of facilities are above the standard compared with other universities. And the system problems or rules that apply are almost $80 \%$ good. In addition, in terms of students there are quite a lot if it is for the standards of private universities.

In addition, the system that is applied to the instructor and the system applied to students, has been implemented starting from the lecturer during the teaching process, the check lock first, absent on line at the time of teaching, and then when depositing the value online. In addition, the university and the rector of managing the sources of funds from the foundation are certainly the contributions of educational development (SPP) managed.

\section{Obstacle factor}

The factor that is a barrier and the challenge faced by Bosowa University is the availability of human resources, namely educators and education personnel. The lecturer as an educator, of course can not be separated from the shortcomings that cause the obstruction of one of the planning of the institution. The obstacle. Based on the results of the observations of the authors from the results of interviews that: one of them is students who are less obedient to the rules such as late paying for Education Development Donations (SPP). However, this problem can be resolved when you want to take the exam. In addition, the University of Bosowa wants to 


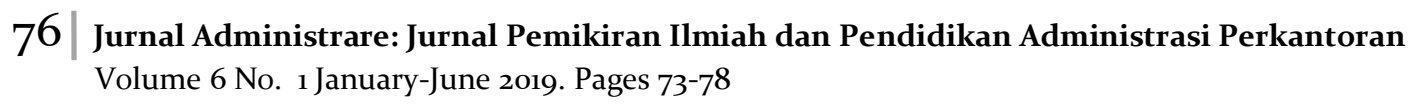

open a Postgraduate Doctoral Program which is an academic obstacle that is not sufficient for educators in the sense that the lecturers do not have as many professors or qualify. Besides that, in their daily lives there are still human resource characters who are used to old patterns. However, only a small part but overcome it, by means of training and courses, close together and shown by new patterns made by the Chancellor of the University.

Besides that, sometimes students violate the rules, protest, that's where a family approach is taken between children and parents so that they need persuasion. Besides that, another obstacle is if there is a change in the system from the Ministry of Research, Technology and Higher Education (KEMENRISTEKDIKTI) because if it happens then it will be a long time to adjust and be studied first, especially from the requirements to get an accredited institution whether A or B.

These things resulted in the obstacles experienced at Bosowa University so that his dream was not realized to open the Postgraduate Doctoral Program. All of the above matters require a process and require time to fix several years in the future that can be realized so as to achieve its vision and mission, one of which being an international university.

\section{CONCLUSION}

The determinant factors in transformational leadership carried out by the Chancellor of the University of Bosowa can be seen from two factors, namely: university supporting factors and inhibiting factors. Supporting factors: provide an illustration that the Chancellor of Bosowa University as the leader of the Institute has networks both at the local, regional, national and international levels. In addition, it is supported by adequate facilities to support the learning process. So that it can become a well-known university at the national level. However, there are obstacles in developing universities, namely: the availability of human resources or teaching staff is still very limited.

\section{REFERENCES}

Adams, A. (2011). Mapping a strategic approach to HR leadership. Strategic HR Review, 11(1), 31-36. https://doi.org/10.1108/14754391211186296

Anderson, M. H., \& Sun, P. Y. T. (2015). The downside of transformational leadership when encouraging followers to network. The Leadership Quarterly, 26(5), 790-801. https://doi.org/https://doi.org/10.1016/j.leaqua.2015.05.002

Antonakis, J., \& House, R. J. (2014). Instrumental leadership: Measurement and extension of transformational-transactional leadership theory. The Leadership Quarterly, 25(4), 746771. https://doi.org/https://doi.org/10.1016/j.leaqua.2014.04.005

Cetin, M. O., \& Kinik, F. S. F. (2015). An Analysis of Academic Leadership Behavior from the Perspective of Transformational Leadership. Procedia - Social and Behavioral Sciences, 207, 519-527. https://doi.org/https://doi.org/10.1016/j.sbspro.2015.10.122

Falk, I. (2013). Designing effective leadership interventions: a case study of vocational education and training. Leadership \& Organization Development Journal, 24(4), 193-203. 
https://doi.org/10.1108/01437730310478066

Hetland, J., Hetland, H., Bakker, A. B., \& Demerouti, E. (2018). Daily transformational leadership and employee job crafting: The role of promotion focus. European $\begin{array}{lll}\text { Management } \quad \text { Journal, } & \text { 746-756), }\end{array}$ https://doi.org/https://doi.org/10.1016/j.emj.2018.01.002

Kragt, D., \& Guenter, H. (2018). Why and when leadership training predicts effectiveness: The role of leader identity and leadership experience. Leadership \& Organization Development Journal, 39(3), 406-418. https://doi.org/10.1108/LODJ-11-2016-0298

Li, W.-D., Arvey, R. D., Zhang, Z., \& Song, Z. (2012). Do leadership role occupancy and transformational leadership share the same genetic and environmental influences? The Leadership Quarterly, 23(2), 233-243. https://doi.org/https://doi.org/10.1016/j.leaqua.2011.08.007

Mac Ruairc, G. (2013). Leadership, capacity building and school improvement: concepts, themes and impact. Taylor \& Francis.

Maheshwari, S. K., \& Yadav, J. (2019). The role of HR in leadership development. Development and Learning in Organizations: An International Journal. https://doi.org/10.1108/DLO-11-2018-0141

Mascia, A., Dal Pubel, L., \& Sartori, M. (2013). A vision of effective leadership: An Italian perspective. In Advances in Educational Administration: Vol. 20. Collective Efficacy: Interdisciplinary Perspectives on International Leadership (pp. 12-215). https://doi.org/doi:10.1108/S1479-3660(2013)0000020012

Miles, M. B., Huberman, A. M., \& Saldana, J. (2014). Qualitative data analysis: A method sourcebook. In CA, US: Sage Publications.

Nasila, J. W., \& Akib, H. (2014). Participative leadership of village head based local wisdom" H4" in district. Suwawa, Bolango Bone Regency, Gorontalo province Indonesia. Global Journal of Business, Economics and Management, 4(1), 29-36.

Organizational Effectiveness. (2013). Leadership \& Organization Development Journal, 34(1), 98-100. https://doi.org/10.1108/01437731311290008

Phaneuf, J.-É., Boudrias, J.-S., Rousseau, V., \& Brunelle, É. (2016). Personality and transformational leadership: The moderating effect of organizational context. Personality $\begin{array}{llll}\text { and Individual } & \text { Differences, } 35 .\end{array}$ https://doi.org/https://doi.org/10.1016/j.paid.2016.06.052

Saggaf, M. S., Akib, H., Salam, R., Baharuddin, A., \& Kasmita, M. (2018). The Quality Analysis Of Academic Services.

Saggaf, M. S., \& Salam, R. (2017). Examining Academic Service using Importance Performance Analysis (IPA).

Saggaf, S., Salam, R., Kahar, F., \& Akib, H. (2014). Pelayanan Fungsi Administrasi Perkantoran Modern. Jurnal Ad'ministrare, 1(1), 20-27.

Salam, R. (2015). Penerapan Fungsi Administrasi Perkantoran Modern berbasis Daya Saing 
78 | Jurnal Administrare: Jurnal Pemikiran Ilmiah dan Pendidikan Administrasi Perkantoran Volume 6 No. 1 January-June 2019. Pages 73-78

Organisasi dalam menyongsong MEA 2015. SEMINAR NASIONAL "Revolusi Mental Dan Kemandirian Bangsa Melalui Pendidikan Ilmu-Ilmu Sosial Dalam Menghadapi MEA 2015” Himpunan Sarjana Pendidikan Ilmu-Ilmu Sosial Indonesia, 1, 186-190.

Salam, R., \& Rosdiana. (2016). Penerapan Fungsi Administrasi Perkantoran Modern Berbasis Daya Saing Organisasi dalam Menyongsong MEA 2015. SEMINAR NASIONAL "Revolusi Mental Dan Kemandirian Bangsa Melalui Pendidikan Ilmu-Ilmu Sosial Dalam Menghadapi MEA 2015" Himpunan Sarjana Pendidikan Ilmu-Ilmu Sosial Indonesia, 1(2016), 186-190. Fakultas Ilmu Sosial Universitas Negeri Makassar.

Taylor, S., Pearse, N., \& Louw, L. (2013). Development of a philosophy and practice of servant leadership through service opportunity. Proceedings of the European Conference on Management, Leadership \& Governance.

van Dierendonck, D., Stam, D., Boersma, P., de Windt, N., \& Alkema, J. (2014). Same difference? Exploring the differential mechanisms linking servant leadership and transformational leadership to follower outcomes. The Leadership Quarterly, 25(3), 544562. https://doi.org/https://doi.org/10.1016/j.leaqua.2013.11.014 